\title{
Akan Indigenous Knowledge Systems and the Christian Faith in Ghana: A Review of the Major Works of Robert Rattray
}

Kwabena Opuni-Frimpong' 1

${ }^{1}$ Department of Religious Studies, Kwame Nkrumah University of Science and Technology, Kumasi-Ghana.

\begin{abstract}
The Western missionaries' attitude towards Asante indigenous belief systems created the impression that Christianity was unable to live side by side with Asante indigenous knowledge systems. The missionaries ended up creating tension between the Christian faith and the pre-missionary cultural values. The indigenous knowledge systems that informed the world views of the people were not considered an integral part of the available resources for the shaping of the Asante Christian worldview. The Salem communities, for example, were set up to facilitate the disconnection of the new converts from their cultural past. This study is about the available pre-missionary Asante indigenous knowledge systems that Robert Sutherland Rattray after thorough studies published and made available to facilitate all aspects of the Asante life especially interpretation and transmission of the Christian faith. With a critical examination of the various major works of Robert Rattray and observation of Asante cultural and Christian activities, the study identified some specific areas that the Asante indigenous knowledge systems have lived side by side with the Christian faith. The study concludes with a call for respect, pride and intentional exploration into the indigenous knowledge systems to serve the Asante and other Akan Christian needs.
\end{abstract}

Correspondence:

Kwabena Opuni-Frimpong

Email: opuni@hotmail.com

Publication History

Received 24th June, 2021,

Accepted 9th August, 2021,

Published online 17th August, 2021.

Keywords: Robert Sutherland Rattray, Indigenous Knowledge System, Christian Faith, Asante, Cultural Values.

\section{INTRODUCTION}

Robert Sutherland Rattray who studied the Asante cultural values at the beginning of the $20^{\text {th }}$ century established the existence of Asante indigenous knowledge systems in series of publications. ${ }^{1}$ In his various documentations on Asante, Rattray sought to make available the intellectual weight in Asante cultural values that must be considered in all facets of life, especially in the Christian faith. ${ }^{2}$

Andrews Walls has opined that when the Gospel crosses cultural boundaries it adopts the cultural categories of its new environment for expression and survival. ${ }^{3}$ However, the early Western missionaries who worked among the Akan communities did not perceive the capabilities of African traditional belief systems for the disclosure of God. For Walls, 'the early missionaries had little in their theology to cause them to look

1 Robert Sutherland Rattray 1881-1938, was an early student and interpreter of Asante indigenous knowledge systems.

2 Some of the works of Rattray, R. S on Ashanti include. Ashanti. (London: Oxford University Press 1955). Religion and Art in Ashanti.(London: Oxford University Press, 1927). Ashanti Law and Constitution. (London: Oxford University Press, 1929) Ashanti Proverbs. (London: Oxford University Press, 1916).

3 Andrew Walls. The Cross-Cultural Process in Christian History (New York: Orbis Books, 2002). 
for God in Africa traditional religion.' ${ }^{4}$ In the effort to explain the Western missionaries' unpreparedness to use Akan cultural values for Christian translation and interpretation, Kwame Bediako has argued that the challenge was as a result of the European value setting for non-Europeans. For Bediako, 'what was observed in Africa was understood and interpreted, not in terms of Africa, but in terms of Europe, that is, of the European value-setting for the faith. ${ }^{5}$

S. G. Williamson has observed that the primary task of the missionaries among the Akan people, was the disassociation of Christians from the indigenous belief systems. ${ }^{6}$ Williamson observed missionary attitude towards Asante religion as 'the Christian faith and Asante religion reveal themselves as basically different. They meet without a common viewpoint and with fundamentally different emphasis. They constitute two different levels of religion, able to view each other from afar but find no ground of fellowship. ${ }^{7}$ Williamson noted that 'the missionary's attitude was, without doubt, unfavourable to Asante customary ways and traditional life. He understood his purpose in terms of calling the convert from traditional associations in heathen surroundings into a new way of life. ${ }^{8}$ Efforts were therefore made in order to work towards the extinction of Asante indigenous religious practices without intellectual exploration. The destruction of Asante indigenous belief systems became an integral part of missionary efforts. As Williamson further noted, 'the primary task of missionaries among the Asante was the destruction of traditional superstition and the implantation of the Christian faith. ${ }^{9}$ If Williamson's observation was right then it would be difficult on the part of missionaries to explore the integration between the Christian faith and Asante indigenous belief systems.

Kwame Gyekye has argued for the existence of Akan indigenous knowledge systems in oral literature, thoughts and actions of the people in his African cultural values. According to him, 'African philosophical thought is expressed both in the oral literature and in the thoughts and actions of the people. Thus, a great deal of philosophical material is embedded in the proverbs, myths and folktales, folk songs, rituals, beliefs, customs, and traditions of the people, in their art symbols and their socio-political institutions and practices.' ${ }^{10}$ In expressing a similar position with Gyekye, Nana Addo Dankwa noted that 'our forefathers, who at their time had not developed the art of writing and recording events, gave special significance to their culture and rituals by using such sculptural items as stools, dolls, etc. as symbols which were made to represent various important historical events. In effect, these special sculptural items became their books in which were embedded their early history, practices and experiences for posterity." 11

Theology that meets the needs of the local people must respond to the circumstances of the people and their indigenous knowledge systems. According to Robert Schreiter, 'in all these instances, however the theology coming from them might be understood, there was that common concern: making sense of the Christian message in local circumstances'. ${ }^{12}$ The effort to make sense of the Christian message in local circumstances must definitely pay attention to the indigenous knowledge systems of the people before their encounter with the missionaries.

It has been observed that the Asante indigenous knowledge systems that early Western missionaries sought to distance their converts from have lived side by side with the Christian faith more than a century after Rattray's observation and interpretation. The study seeks to articulate the suggestions made by Rattray for the healthy relationship between the Christian faith and Asante cultural values at the beginning of the $20^{\text {th }}$ century and further points to how they provide grounds for Christian interpretation, understanding and integration in the future of Asante Christian faith.

\footnotetext{
4 Walls. The Cross-Cultural Process in Christian History, 120.

5 Kwame Bediako. Theology and Identity The impact of culture upon Christian thought in the second century and modern Africa. (Oxford: Regnum Books, 1992), 235.

6 S. G, Williamson, Akan Religion and the Christian Faith, (Accra: Ghana University Press, 1965).

Williamson, Akan Religion and the Christian Faith,), 151.

Williamson. Akan Religion and the Christian Faith, 56.

Williamson. Akan Religion and the Christian Faith, 54.

${ }^{10}$ Kwame Gyekye, African Cultural Values, (Accra: Sankofa Publishing Company 1996),13

11 Nana Addo Dankwa III. The Institution of Chieftaincy in Ghana. The Future. (Accra: Konrad Adenauer Foundation 2004$)$.72.

12 Robert J. Schreiter,. Constructing Local Theologies. (New York: Orbis Books, 1985.) 2.
} 


\section{METHODOLOGY}

The research was pursued through primary and secondary sources. Observations were conducted on Asante indigenous knowledge systems in some palaces, communities and congregations. Rattray's major works on Asante i.e., Ashanti Proverbs, ${ }^{13}$ Religion and Art, ${ }^{14}$ Ashanti Law and Constitution ${ }^{15}$ and Ashanti ${ }^{16}$ were extensively examined together with other relevant available materials on the engagements of the African cultural values with the Christian faith. Through observation on the interplay of Asante cultural values and Christian faith in some Asante congregations of the Presbyterian Church of Ghana, Methodist Church Ghana, Anglican Church and the Roman Catholic Church and traditional activities in the communities, the study identified some specific areas that Asante cultural values and Christianity have lived side by side. The study as a qualitative study focused on Asante as one of the major Akan communities on its search for the indigenous knowledge systems and draws lessons for other Akan Christian communities.

\section{Robert Rattray and the Reality of Asante Indigenous Knowledge Systems}

Robert Sutherland Rattray 1881-1938, was an early student and interpreter of Asante indigenous knowledge systems. He provided grounds for an intellectual justification of the indigenous resources of the Asante of Ghana and therefore is presented as a key witness and interpreter of Asante indigenous knowledge systems. As a military Captain with the Royal Army and a legal officer, he initially came to work with the Colonial Administration of the then Gold Coast. However, when the colonial administration set up the Anthropological Department he was seconded and appointed as the first Head of the Anthropology Department. The primary intention of the Department was to document the indigenous resources of the Asante people to avoid their extinction. ${ }^{17}$

When he started the work, he became convinced that the very future of the Asante society was deeply connected to the integration of their indigenous resources in whatever developmental programmes that were being pursued. He added passion and significance to the original philosophy and policy of the colonial government to the study of Asante cultural life. This is evident in the documentation and availability of the findings in his various works on Asante.

The colonial administration had earlier on identified that to be able to establish colonial control there was the need to work through the existing traditional leadership institutions. That, however, required some level of understanding of the cultural practices. The colonial government admitted that 'an accurate acquaintance with the nature, habits, and customs of alien populations is necessary to all who have to live and work amongst them in any official capacity, whether administrators, executive officers, missionaries, or merchants because in order to deal effectively with any group of mankind it is essential to have that cultured sympathy with them which comes of sure knowledge. ${ }^{18}$

\section{Moving into the Future with Asante Cultural Values}

The policy to study Asante indigenous knowledge systems was primarily to help the British colonial authority deal effectively with indigenous people. In a sense, Rattray and all the other staff of the administration were required to have some level of understanding of the indigenous knowledge systems of the people they functioned within. Beyond the efficiency of the staff, the usage of Asante indigenous intellectual resources was considered as a political strategy for penetrating the political thought system of the people. According to Rattray 'the Indirect Rule policy of the British Administration was pursued through the traditional leadership system of the people. Knowledge of Asante legal system was of paramount importance to the local Administration, as it engaged in framing Native Jurisdiction Ordinances, in schemes for the working of Native Tribunals, and in planning for Indirect Rule'. ${ }^{19}$

Rattray's interest in the study of Asante indigenous intellectual resources however, went beyond the policy of the colonial administration. The depth of Rattray's study of Asante indigenous people and their

${ }_{13}$ Robert S, Rattray, Ashanti Proverbs (London: Oxford University Press 1916).

14 Robert. S, Rattray, Religion and Art in Ashanti. (London: Oxford University Press, 1927).

15 Robert. S, Rattray,-Ashanti Law and Constitution (London: Oxford University Press 1929), viii.

16 Rattray, Ashanti (London: Oxford University Press 1955).

17 Rattray. Religion and Art in Ashanti.

18 Rattray. Ashanti, 5.

19 Rattray, Ashanti Law and Constitution,.v. 
cultural resources demands a deeper explanation. Rattray connected the very future and survival of the Asante people to the study and preservation of their indigenous intellectual resources. He observed that "the Law and Constitution of these people were evolved, and finally based, upon the indigenous beliefs, is to suggest something that goes deeper than the exposition of an interesting academic theory. It is to state a fact of considerable significance in the field of practical West African politics today. Upon the correct application of this knowledge must, I believe, depend on our satisfactory tutelage of this people, and ultimately their own success in self-government." ${ }^{20}$

The discussion of self-government was not a serious issue on the agenda of the colonial government at this stage. For Rattray to connect 'satisfactory tutelage' that would lead to 'ultimately their own success in self-government' at this moment was to suggest that he saw a future which the others had not seen, a future whose disclosure and sustenance would depend on the preservation of the indigenous intellectual resources of the Asante people.

\section{The Study of Asante Indigenous Intellectual Resources and Future Self-Governance}

The connection between the study of Asante indigenous intellectual resources and self-governance explains the depth and approach Rattray adopted towards the study of the Asante indigenous knowledge systems and its people. Knowledge in the cultural practices was not just to determine his effectiveness and efficiency as a colonial administrator. He saw the very survival of the people in that discipline. The issue about selfgovernance brings to mind the availability of leadership. The colonial authorities had ruled the Gold Coast with little participation of the indigenous people. The idea of self-government was on the assumption that the colonial authorities would leave the political scene for the local people to run their own political affairs. Rattray in the attempt to point to how the future Asante involvement in governance should evolve suggested a deeper connection with indigenous resources in leadership development of the Asante people who aspired to take up the future leadership of the nation. But what kind of indigenous leadership resources did Rattray witness among Asante society?

Towards the leadership formation of the Asante people, Rattray addressed the issue of the inferiority complex of the educated Africans. The inferiority complex of the educated Africans relates to their interaction with their Western counterparts. The educated British exhibited confidence in performance as compared to the African educated people who might have considered themselves inferior. The inferiority complex of the educated Africans can however be addressed by paying attention to the study of their own past. According to Rattray, 'if the educated African possesses an Inferiority complex, a study of his own past must surely help to dispel it.' 21

If the educated Africans possessed an inferiority complex as Rattray speculated, then the British colonial presence might be a major reason. The British colonial officers took major leadership positions in the military, government and the law courts. The leadership understandings and qualities that they exhibited were informed by the British prevalent leadership values back at home. Asante people who were in traditional leadership though had received leadership formation from the indigenous formation patterns, were not as equally prepared in British leadership systems as their British counterparts. Though both the British colonial officers and the educated Asante had all received leadership formations, the cultural context that the formation took place varied. The leadership institution that was available to the Asante people was built around the Chief and his traditional leaders. But how did the British colonial officers relate with Asante leadership values and indigenous intellectual resources?

\section{The Un-Fair Relationships}

Rattray further considered missionary attitude towards Asante indigenous resources as unfair. He insisted that 'I have already been at some pains to point out elsewhere that we have been most unfair in judging these outward signs; yet that is what the historians have uniformly done. ${ }^{22}$ Rattray suggests that cultural practices should not be assessed by the outward practices alone. There is a need for exploration into the values behind the practices. The unfairness in missionary education offered to Asante people became visible when some

\footnotetext{
20 Rattray, Ashanti Law and Constitution,. vi.

${ }_{21}$ Rattray. Ashanti Law and Constitution, viii.

22 Rattray. Religion and Art in Ashanti, 131.
} 
of the educated, who actually did not adequately understand the wisdom in the cultural practices, became unsympathetic with their own cultural past and people.

Asante cultural practices admittedly had known some corruption, but that did not suggest rejection and suspicion of its usage as intellectual and theological resources. According to Rattray, the pre-missionary African religious practices were not different from those of Europe when they first encountered the Christian faith. Rattray advised that European missionary engagements with African pre-missionary religions must be informed by European Christian history. He stated, 'foolish and childish in the extreme as many of these beliefs may seem to us, we must realize how terribly real they still are over vast areas of the African continent, where they persist in spite of the restraint of paternal administration and the steady advance of civilization. We should be careful to read the history of our own not very remote past, before, in a spirit of pious indignation; we sit in judgment upon the African.' ${ }^{23}$

It will however take African Christians who love their own country who will bring the change by drawing the inward power as they keep the best in the African cultural values. He stated, 'I am convinced, however, that in this very factor lies the means by which our ideal may be attained, and that it is from Christianity and Christian Missions, Colonial Administrations and Africans who love their own country will yet come to draw that inward power which alone will justify the retention of the best in the Africans' culture and beliefs. ${ }^{24}$ In the effort to work towards the retention of the best in African culture, Rattray identified Christianity and Christian mission as part of the key institutions that must accept the responsibility. But were Christian leaders ready for the suggestion that Rattray made? Did the existing Christian leadership formation patterns have room to accommodate Asante indigenous intellectual resources?

\section{Akan Indigenous Resources and Christian Leadership Formation}

The significance of the study of Asante indigenous resources was related to Akan Christian leadership formation. Training of missionaries and Christian leaders, according to Rattray, must be informed by cultural insights. He observed that, 'I sincerely hope that some of this material will be of value to African missionaries. I have always maintained that necessary and valuable as anthropological training is to the administrator or merchant it should be an indispensable adjunct to the training of the missionary. ${ }^{25} \mathrm{He}$ further postulated on the potency of Asante belief systems. Rattray stated, 'I sometimes think that, had these people been left alone to work out their own salvation, sooner or later, perhaps, some African Messiah would have arisen and swept their pantheons and their religion clean of the suman (fetish). Then West Africa might have become the cradle of a new religion, which acknowledges one Great Spirit, Who, being one, nevertheless manifested Himself in everything around them, and taught men to hear His voice in the flow of His waters and in the sound of His winds among the trees. ${ }^{26}$

Christian leadership formation did not integrate Asante cultural values into its curriculum. The effort was made to disintegrate and in some instances destruction of the cultural practices. The effort subsequently led to tensions between the Christian faith and the indigenous knowledge systems.

\section{Retention of the Best in Asante Cultural Values}

The Asante people were considered as people who were capable of making a significant contribution to their own cultural values, growth and survival as well as contributing to the universal community. Rattray, however, connected Asante contribution to the world in terms of knowledge and progress to their ability to preserve their indigenous resources and heritage. He therefore advised, that 'Asante must guard the national soul of their race and never be tempted to despise their past. Therein lies the sure hope that your sons and daughters would one day make their own original contributions to knowledge and progress. ${ }^{27}$ Asante sons and daughters, Rattray suggests, could not change their cultural identity. Their contributions to the world therefore must not appear to be 'inferior' to their European colonial masters. The possibility of building selfconfidence, however, was further connected to the ability not only to preserve indigenous resources but the

\footnotetext{
23 Rattray. Religion and Art in Ashanti, 34.

${ }^{24}$ Rattray. Ashanti Law and Constitution,.x.

25 Rattray. Ashanti, 10.

${ }_{26}$ Rattray. Religion and Art in Ashanti,. 24.

27 Rattray. Religion and Art in Ashanti, ix.
} 
willingness and pride to intentionally discover resources from the cultural environment for the purpose of making significant contributions to the global community.

Asante contribution to the world community was identified with their cultural identity. But what could a people who feel ashamed of their cultural past and their ancestors do with such an identity? The people who can make significant contributions should be people who have built within themselves inner confidence and power. Inner confidence is what Asante people would need to build a tradition, which could sustain itself in its contribution to the world. Inferior people are unstable and lack the creativity and originality that they need to make a contribution. They may be compelled to imitate others for acceptance and approval.

The study of a people's past, for Rattray, creates in them 'the awareness of what is good in their own cultural practices. They are, moreover, able to build in themselves inward power. ${ }^{28} \mathrm{He}$ therefore sought to involve Christian missionaries, colonial authorities and Africans to consider the importance of studying the cultural past to discover the positive part of their cultural heritage.

\section{Tensions, Unsympathetic Attitudes and the Need for Integration}

Rattray saw the very national weight of the Asante in the identification of their cultural identity. Their past was not to be viewed with shame in relating to European cultures and civilization. Asante people, in the observation of Rattray, rather had to develop their sense of pride in their own past and cultural heritage. The relationship between Akan cultural values and the Christian faith nonetheless, was characterised by tensions, unsympathetic attitudes and efforts towards disintegration. Rattrays reason for tension between the Christian faith and the Asante indigenous belief systems is affirmed by Schrieter. According to him, 'there was a growing sense that the theologies being inherited from the older churches of the North Atlantic community did not fit well into these quite different cultural circumstances. ${ }^{29}$

The urgency of Rattray's study was determined by the visible rejection and destruction of indigenous values and knowledge systems by Asante people, especially those who had had some encounter with European patterns of education and missionaries. Rattray summed up the phenomenon in the following words, "the educated African, however, has been cut off from and is out of sympathy with, the life of his own people. He has learned in nine cases out of ten, if he has not actually been taught, to despise his own illiterate brethren and the unlettered past of his race. Concerning that past, he really knows little or nothing, and generally cares less'. 30

Rattray acknowledged the tension that existed between Asante Christians and their cultural values. The tension emanated from the education that the mission schools offered. According to him, if an Asante person has been educated in one of the mission schools, 'then his whole training, until quite recently, has been one in which it has not appeared orthodox or even conceivable to his teachers that there might be something in the African's own culture and religious beliefs worthy of retention side by side (for a time at least) with the ethical teachings of Christian theology. Such being the case, can one wonder that African pupils and converts alike have been quick to see and very ready to follow a trend of thought which denied, or ignored, the possibility of anything useful or good or ethical existing in the African's own religion. ${ }^{31}$

The result has been that the cultured and semi-educated Africans alike (with a few exceptions) when asked about the beliefs of their own people, 'unconsciously paint them in all the unreal and exotic colours with which their new training and their new environment have taught them to regard them. They feel, and they have been trained to believe, that they are brands plucked from the burning. It is almost impossible that such persons can be sympathetic with their own past, a past which after all few of them have ever really known, seen, or clearly understood. ${ }^{32}$

Rattray considered some aspects of Asante cultural resources worthy of retention. Moreover, they could live side by side with Christian understandings and practices. Missionary education however, did not adopt that approach of integration in its patterns of education. Products of missionary education developed a hostile attitude in their relationship with indigenous resources. In a sense, Rattray would want his readers

28 Rattray. Religion and Art in Ashanti, ix.

29 Schreiter. Constructing Local Theologies. 1.

30 Rattray. Ashanti,8.

31 Rattray. Ashanti,87.

32 Rattray. Ashanti, 87. 
to believe that the tension between the Christian faith and Asante worldview was an outcome of missionary education. The notion of Asante people who received missionary education that they were better than their uneducated people, explains why some of them became so unsympathetic to their people and indigenous resources.

The Christian education from the mission schools did not encourage the Akan students to search for sound ethical teachings from their cultural heritage. The whole training from the mission schools, 'has been one in which it has not appeared orthodox or even conceivable to his teachers that there might be something in the African's own culture and religious beliefs worthy of retention side by side (for a time at least) with the ethical teachings of Christian theology. ${ }^{33}$

The Akan educated Christian did not consider integration of the Akan cultural values for possible living side by side with the Christian faith because the trend of their thoughts did not allow them to do so. Rattray argues that, "African pupils and converts alike have been quick to see and very ready to follow a trend of thought which denied, or ignored, the possibility of anything useful or good or ethical existing in the African's own religion. ${ }^{34}$

\section{The Salem Communities and the Destruction of Akan Cultural Values}

The creation of Salem in Akan societies separated Akan Christians from their families and cultural practices. Church members were asked to move from their homes to settle in Salem. The Salem pattern, according to Noel Smith, was repeated wherever the Basel Mission for example established congregations. ${ }^{35}$ In other instances, the converts were forced to separate from their families as a result of their conversion to Christianity. According to him, 'the missionaries thought that pastoral care of the converts was made much easier; in the unified Christian settlements. The Christian community gathered for devotions every morning and for the Friday evening prayer meeting and organised its life around the mission stations. ${ }^{36}$ The missionaries were moreover afraid of the possibility of their new converts contaminating themselves with traditional practices. All efforts were therefore made to disassociate them from the traditional communities and their practices.

The Basel Mission, and to some extent other missions as well, 'adopted a policy of separating their converts entirely from the cultural practices lest the social and artistic attractions of the old life should lead them to forget their new faith: a policy which may have been inevitable from the point of view of the Christian evangelist, but which led to a most unfortunate cleavage in the life of the community. ${ }^{37}$ Sanctions were imposed on church members who participated in traditional practices like funerals, marriages and festivals. The approach of separation and disintegration did not answer the questions of the Akan Christians. Answers were needed for questions such as how does an Akan person become a Christian and still remain Akan? How can an individual become a Christian and still enhance the indigenous intellectual resources for theological construction?

Smith has observed that no matter the intentions of the missionaries, the Salem pattern did not encourage integration in the community. According to him, "we might almost say that in their zeal to establish separated Christian communities, the missionaries asked too much and failed to realize that the claims of kin could not be easily set aside, however great the attractions of the new religion were. There were good reasons for their attitude at the time and we can only sympathise with them; yet the failure to come to terms with the wider community has left the problem of the fruitful expression of the Gospel in African idiom still unsolved.' 38

Williamson has observed that Christianity in the Akan area was fashioned according to Christianity in the West. According to Williamson, 'the polity and organization, the liturgies and devotional expressions, the discipline and instruction, the total outlook derives directly from the parent missionary societies and the churches supporting them. The Christianity of the Akan area proves to be the denominational Christianity of the West. ${ }^{39}$

\footnotetext{
33 Rattray. Ashanti, 88.

34 Rattray. Ashanti, 88.

35 Noel Smith. The Presbyterian Church of Ghana,1835-1960 (Accra: Ghana Universities Press, 1966), .49.

36 Smith. Presbyterian Church of Ghana 50.

37 Smith. The Presbyterian Church of Ghana 50.

38 Smith, The Presbyterian Church of Ghana 1835-1960, 104.

39 Williamson. Akan Religion and the Christian Faith, 165.
} 
However, African indigenous religions were considered primitive, heathen, fetish and animistic. Williamson indicated that, 'the people to whom Europe offered its faith were themselves possessed with religious practices and rites which came to bear a variety of descriptive names. As for the Portuguese in the fifteenth century, so in the eyes of nineteenth-century administrators and missionaries, the indigenous religious practice was idolatry or superstition, or came to be known, inaccurately, as fetishism. In the scientific and academic classification of the world's religions, Akan religion belongs to the category of animistic religions.' ${ }^{40}$ The varied descriptions that were given to Akan indigenous belief systems did not encourage intellectual exploration into the practices in order to discover resources for Christian expression.

\section{Christianity and Akan Cultural Values still Living Side by Side}

Rattray's encounter with Asante has indicated that western missionaries made significant efforts towards disassociating members from Akan cultural values. The efforts have been seen in the sense of inferiority complex among Akan educated Christians, disconnection of the Akan Christians from their cultural practices through the Salem communities, the unwillingness to search for ethical and theological values from the African traditional religions, and the sustenance of the sense of shame in the African past. The legacies of such western missionaries towards Akan indigenous knowledge systems have lived on even beyond the postmissionary Akan Christianity.

The missionary attitude towards the cultural values subsequently has led to tensions between the Christian faith and the Akan cultural values. Some churches established in Akan communities debar Christian royals from becoming chiefs and other traditional leaders. Christian royals who disobey such church instructions have been subjected to Christian discipline including withdrawal from the Holy Communion. Okyeame Ampratwum who was a lay leader, Catechist in the Presbyterian Church of Ghana was asked to step down when he accepted to be Okyeame. ${ }^{41}$ Nana Addo Dankwa III who was a participant at the Holy Communion before he accepted to become a chief was denied the holy communion. He was re-instated in the last years of his reign before his death. ${ }^{42}$

Traditional drums and other musical instruments were rejected during Christian worship. Those who defiled the instructions were disciplined to the point of dismissal. Ephraim Amu a renowned musicologist was disciplined by the Presbyterian Church of Ghana for his insistence to go to church and preach in traditional cloth. Despite the tension between the Christian faith and Akan cultural values and the various efforts made towards the destruction of the indigenous belief systems, the best in Akan cultural values have sustained and have lived side by side with the Christian faith.

The fact remains that contemporary Christian practices in Asante communities have been influenced and shaped by Asante indigenous cultural categories for its understanding and expression. Asante indigenous cultural values are living still in contemporary Asante Christianity. Asante Christians must therefore be true to the indigenous resources even if early western missionaries did not give that understanding and encouragement.

The influence of the Christian faith by Asante religious and cultural thought systems can be examined in matters of the Asante concept of God, analysis of Akan concepts, proverbs and stories also demonstrate Akan societal knowledge and values, which can be considered as the educational values for indigenous formation patterns. The symbols and concepts depict value systems in diverse areas. Akan indigenous knowledge and value system available for examination to live side by side with Asante Christianity include traditional diplomacy and courtesy, constitution and legal systems, political and leadership systems, spirituality and moral systems, arts and craft systems, health and healing systems, crises and bereavement management systems, environmental protection and restoration systems, communication and information management systems, documentation and celebration of historical events, philosophical thought and ideological construction systems, defence and security systems, aesthetic and beautification systems, marriage, family life and community building systems. ${ }^{43}$

Over a century of Rattray's work among the Asante people, it has proven that the cultural values of Asante are still in existence despite the efforts by western missionaries to disconnect Asante Christians from

\footnotetext{
40 Williamson. Akan Religion and the Christian Faith, ix.

${ }^{41}$ Interview with Okyeame Ampratwum June 1, 2004 Asante Mampong.

42 Interview with Nana Addo Dankwa III November 22, 2004 Akropong Akuapem.

43 Interview with Nana Addo Dankwa III November 22, 2004 Akropong Akuapem.
} 
their pre-missionary past. The Asante indigenous knowledge systems have facilitated the translation and the expression of the Asante Christian faith by Ghanaian Christian theologians and scholars even though they were not acknowledged as such by Western missionaries.

With the capabilities that the Asante indigenous knowledge systems have demonstrated over the years in Christian expression and translation, it is expected that Asante Christians will acknowledge their own cultural past with respect and attach deliberate and conscious pride to their cultural values as key Christian partners as they journey into the future.

\section{Akan Christian Marriages}

Akan traditional family life systems have lived side by side with Christianity over the years. Marriage is initiated by two young people who are connected with love and a common future. The initiative of the young people towards marriage however, brings their two families together for the marriage journey of the couple. The families come together for the marriage union with the exchange of traditional gifts and sharing of pieces of advice with the new couple and others who participate in the ceremony. The authenticity of Akan marriage is determined by the two families' preparedness to exchange gifts on behalf of their children and families.

God is the initiator of marriage. The Lord God also said, 'it is not good for the man to be alone. I will make a helper suitable for him' (Gen.2:18). Paul also admonished that each man must have his own wife. Paul stated, 'let each man have his own wife, and let each woman have her own husband' (I Cor. 7:2). Jesus's participation in a wedding at Canna makes a wedding an example of a major component in Christian marriage. Christian weddings in Ghana must have registration of the marriage at the law Courts and later follow with church services. Key features in Christian weddings include the exchange of vows, exchange of rings, signing of certificates and giving of gifts and expression of Christian charity.

Traditional marriages have witnessed Christianity living side by side with cultural values in some Akan communities. Church leaders usually participate in the traditional marriages of the families at the various family homes. Church leaders normally witness the traditional marriage processes in which parents and family heads are the key actors. The marriage processes are done according to the cultural marriage values and understanding. Pastors and church elders are invited to say Christian prayers after the exchange of gifts and at the end of the traditional marriage process. While some church delegation to traditional marriages may play active roles it must be noted that church representatives remain observers and not key actors.

Christian marriages in the Asante congregations of both the Presbyterian Church of Ghana and Methodists Church, Ghana, take place in the chapels. The Father of the bride or his representative is invited by the officiating ministers to declare publicly his willingness to hand over the bride to the groom. The declaration follows a question that is usually asked to establish the fact that the traditional marriage according to the cultural values of the family has been acceptably performed. Marriage certificates that are signed by the couples and their parents during the wedding ceremony are witnessed by the officiating ministers and this has been the Akan Christian marriage practice in the mainline churches in the Akan communities over several decades. Akan Christian marriages have become a celebration of the Christian faith and Akan cultural values without much tension. There are tensions in situations where married couples undergo the traditional marriage system and getting blessings from churches becomes a challenge. This is because the couples have not added the ordinance marriage hence some churches have challenges with such couples. The churches that the study focussed however have responded to the tension. The Presbyterian Church of Ghana for example has designed Certificates for married couples who after the traditional marriage opted for church blessings without ordinance marriage.

\section{Akan Christian Naming Ceremonies}

A naming ceremony is an Akan cultural value that brings family members together for the celebration of life. It is a ceremony that indicates acceptance of the new child into the family. It provides children with their cultural identity and reminds the other family members of their unique cultural heritage. The naming ceremony also sets a pattern for conduct and behaviour for the new child and other family members. Children are named after individuals with cherished lifestyles and moral conduct. The children are expected to grow and emulate the moral life of those they have been named after.

One of the mandates that God gave to Adam in the Garden of Eden was to give names to the creation 
of God (Gen. 2:20). The naming of children has remained a common feature in Scripture. The proposal of Elizabeth to name her son John sparked controversy in her family as the name was unfamiliar to the family until the father confirmed it in writing (Luke1:57-80). Scripture affirms that a good name is better than riches (Prov. 22:1). Thus a naming ceremony is a moment of joy in the liturgical order of the mainline churches in Asante.

Naming ceremonies in Akan are done by the church together with the family either in the family house of the couples or in the church. The father of the child is allowed to declare the name of the child and the individual that the child is been named after. Naming ceremonies observed in the mainline congregations noted that the churches and pastors do not take over the selection of the name. The family together with the church pray for the child, parents and others present gifts to the child and the parents. Akan Christian naming ceremony has remained living side by side with the cultural values. Akan naming cultural values have found their way into the Christian liturgy of the mainline churches and the cultural values have subsequently lived side by side with the Christian faith.

\section{Akan Christian Funerals}

Death is a transition to the world of the ancestors according to Akan cultural understanding. The process towards the departure of the dead is very important. It is a determining factor for acceptance in the world of the dead. There is the fear that if an individual's funeral is not properly done, one may not be accepted in the world of the dead. Funerals also provide the opportunity for family members and the general public to participate in the celebration of the life of the departed. Akan funerals are therefore opened to the public without much consideration to participants' religious and cultural backgrounds. Cultural music and dance are major characteristics of the traditional funeral with sharing of meals and drinks. Participants in funerals express their love to the bereaved families with donations intended to help the families settle the funeral expenses.

Funerals and the mourning of the dead by Christians take their roots and examples from Scripture. Scripture instructs that Christians must 'rejoice with those who rejoice and weep with those who weep' (Rom. 12:15). Christian funerals are characterised by sermons, prayers and songs that are geared towards comforting and helping the bereaved families to manage the pain of death. Christian funerals are also intended to draw the attention of those who participate in the service for the need for a closer walk with God. Donations and offerings are made to the bereaved families to offset part of their funeral costs. Memorial and thanksgiving services are held to thank God for the life of the departed and the successful organization of the funeral.

Funerals have gradually become demonstrations of the interface between cultural values and the Christian faith. Funerals in the Presbyterian Church of Ghana and the Methodist Church, Ghana share some similarities. Church members and pastors join the bereaved families to pray after the corpse has been laid in state before permission is granted for public viewing. The corpse is later sent to the church for the Christian service which the pastors handle. At the cemetery, the pastors handle the committal rites but a family member is invited to express the gratitude of the family to all participants in the burial ceremony before the pastors pronounce the benediction. The funeral gathering that invites people to make donations also start with Christian prayers and end with Christian prayers as church members also join in the donations.

There is the impression that traditional funerals have even been taken over by Christianity. Daasebre Osei Bonsu paramount chief of Asante Mampong has opined that the people do not lose their cultural values and presence when they participate in Christian activities during funerals. He has opined that, 'apart from my title Daasebre, I have a Christian name given to me when I was baptized. If I die today, members of my church would ask for some Christian ceremonies. It does not mean that when we perform such ceremonies, then we have neglected or abandoned Asante culture. It is wrong for anybody to assume that a Christian chief has abandoned our culture. ${ }^{44}$

\section{Akan Traditional Symbols, Clergy Stoles and Vestments}

Akan traditional symbols are reflections of deep understandings of life. ${ }^{45}$ They are summaries of the

\footnotetext{
${ }^{4}$ Daasebre Nana Osei Bonsu in Irene Odotei \& George Hagan (ed). The King Returns: Enstoolment of Asantehene Osei Tutu II. (Accra: Institute of African Studies, 2002.) p.133

45 Interview with Sam Prempeh September 1, 2004 Osu Accra
} 
philosophical thoughts and ideologies of indigenous people. Totems are also animal symbols that represent the cultural identity of the people. Traditional symbols are normally displayed on the clothing, regalia and other authority symbols. They are symbols of pride and identity and portray the thoughts and ideals of the people.

Christianity presents its unique symbols. Notable among them are the symbols of the Holy Spirit, the Cross of Christ and the Trinity. Christian symbols are on display in worship materials, architecture, vestments and clergy stoles. They bring deep Christian understandings, history and identity. They are faith and identity materials that are respected and cherished.

Akan clergy stoles and vestments that have become an acceptable norm in the Roman Catholic Church, Anglican Church, Methodist Church, Ghana and the Presbyterian Church of Ghana and they demonstrate how Akan cultural values and Christian symbols have lived side by side. Clergy stoles of the Presbyterian Church of Ghana, for example, have a combination of Akan Gye Nyame Symbols and the Christian symbols of the Cross and the Holy Spirit. During the National Ministers Conference of the Ministers of the Presbyterian Church of Ghana, various stoles were approved and launched by the President of the Conference Rev Dr. J.O.Y. Mante, for Ordained Ministers and Presbytery Chairpersons. The stoles came with the Gye Nyame symbol (indigenous symbol affirming the Sovereignty of God), the logo of the Presbyterian Church of Ghana and the Cross of Christ. ${ }^{46}$ Vestments and stoles of Roman Catholic Church, Anglican Church and Methodist Church Ghana Bishops are engraved with Christian symbols and Traditional symbols and Asante symbols of stool and totems like the Porcupine. The traditional symbols on clergy stoles come with the acceptance and pride of both church members and the pastors. They have become a demonstration of the unique Akan Christian identity.

\section{Traditional Diplomacy and Courtesy at Christian Meetings}

Akan cultural values pay much attention to matters of diplomacy and courtesies. ${ }^{47}$ Basic things like how to greet and behave before traditional elders are very important. An area that attracts much attention is how visitors are received and their missions announced. The person who has arrived is given the opportunity to tell their stories and the purpose of the visit. After welcoming, those visited in turn tell their stories. Other conversations then follow. It is considered disrespectful and uncultured to receive visitors without allowing them to tell their stories or allowing other stories to be told before that of the visitors.

Showing respect to visitors is a very cherished Christian virtue. Scripture admonishes Christians to entertain visitors. The author of the Book of Hebrews indicates, 'do not forget to show hospitality to strangers, for by so doing some people have shown hospitality to angels without knowing it' (Heb. 13:2). Christian gatherings and conferences have retained over the years some cherished Akan courtesies. Districts, Presbyteries and General Assembly meetings of the Presbyterian Church of Ghana have operated a protocol that is at home with the Akan courtesy. At the welcoming ceremonies which always start the meetings, a representative of all the visiting delegates is invited to bring greetings to the hosting Districts and Presbyteries. The hosting Districts and Presbyteries subsequently respond to the greetings with a welcoming address. Though the church courtesy of opening such high-level meetings is dominated by scriptures, history and theology it is also established in the cultural values of the Akan cultural soil. The central themes of traditional leaders who participate in such meetings are words of appreciation to the churches for the churches' contribution to the development of their traditional communities. The business of the church becomes part of the community as they are considered partners in the traditional community. The practice is not unique to the Presbyterian Church of Ghana only. Other mainline churches' meetings follow similar patterns.

\section{Festivals and the Celebration of Historical Events}

Akan festivals are a celebration of historical events. Festivals bring the people together for collective recollections and reflections on their past and in the process seek meaningful participation in the values of the festival as they anticipate a fruitful and prosperous future. ${ }^{48}$ The traditional festivals involve rituals and attention to the ancestors whose deeds are celebrated during the festivals. The traditional festivals moreover,

\footnotetext{
46 Report of Presbyterian Church of Ghana Ministers Conference held at KNUST Kumasi on January 10-14, 2011.

47 Interview with Nana Addo Dankwa III November 22, 2004 Akropong Akuapem.

${ }^{48}$ Interview with Kwabena Nketia May 19, 2004 Madina Accra.
} 
provide the people and their leaders space to thank the Supreme Being for remaining their great provider and protector. The festivals have their climax in the festival gatherings which bring together Government officials, people of other faiths and communities as well as tourists. Akan traditional festivals like Akwasidae Kese in Kumasi and Odwira at Akropong Akuapim end up with Christian Sunday thanksgiving services. ${ }^{49}$

Christian festivals like Christmas and Easter have remained moments of joy and reflection among Akan Christians. The churches also celebrate their anniversaries. It must be noted that traditional festivals' thanksgiving services have also become a recognizable and acceptable part of Akan Christian thanksgiving services. Pastors are invited to the festivals and are allowed to offer prayers for the traditional leaders, the people of the community and the peace and prosperity of the future. Akwasidae Kese in Kumasi and Odwira festivals in Akropong Akuapim end with thanksgiving church services at St Cyprian Cathedral Kumasi and Christ Congregation of Presbyterian Church of Ghana Akropong respectively annually. Akan festivals have indeed lived side by side with Christian celebrations.

\section{Ohene Yesu (Chief Jesus) in Akan Christian Worship}

The Akan traditional leadership is visible and paramount in Akan societies. The chieftaincy institution is the symbol of identity, cultural values and the pride of the indigenous people. The chiefs in the past led the people to fight their enemies and therefore became the symbol of security, victory and prosperity. The values of courage, wisdom, wealth and power of the chiefs become the standards that others desire to emulate.

Accordingly, Jesus is Lord and Saviour for Christians. His birth, death and resurrection have become an inspiration for hope and service for Christians. He is the victorious Saviour who motivates strength for spiritual warfare for Christians in their moments of pain and challenges.

Jesus has been recognized as Agyenkwa (Saviour), Obuafuo (Helper) and Odimafuo (Advocate) in Akan Christian worship. Jesus has also significantly been recognized as Ohene (Chief) in Akan Christianity. Ohene Yesu is noted in Christian hymns, songs, prayers and sermons in the mainline churches. It must however be noted that while the titles of the Ohene are used for Jesus, it does not mean that they worshipped him as Ohene. Jesus is praised and worshipped with the tiles of Ohene. Even though some Christians may show a disconnection with the chieftaincy institution, Ohene Yesu is accepted and loved without any significant hesitation. The Akan Christian's understanding of Ohene Yesu definitely is situated in Akan traditional leadership. The disconnection from the chieftaincy institution renders the titles given to Ohene Yesu meaningless and insignificant. Ohene Yesu is the Akan traditional leadership living side by side with the Christian understanding of Christ. The issue should be how both the traditional Akan and Christians conceive Jesus Christ. It is not just about titles that counts, it is about how the two see and recognise Jesus. The concept of the Ohene however, provides the entry points for the Akan Christian understanding of Christ.

\section{CONCLUSION}

Rattray in his studies of the Akan of Ghana brought out indigenous knowledge systems with a deep intellectual weight that should be explored for the benefit of the future governance of the new state, community development, and Christian expression. Western missionaries, however, described Akan cultural values as fetish, heathen, animistic, barbaric, etc. and did not, therefore, give much theological attention to the indigenous cultural resources. Efforts were made towards the eventual destruction of the traditional religion through the Salem communities, the feeling of shame about the past, and the sense of inferiority complex of the Akan people in their relationship with their European counterparts. Rattray recommended for the Akan Christians to attach pride and respect to their own cultural values and work towards the retention of the strong and positive parts of their indigenous knowledge systems.

The study has noted that despite the efforts to work on disintegration and destruction of the Akan cultural heritage, the Akan indigenous knowledge systems have lived sided by side with the Christian faith since Rattray's first publication in 1916. The co-existence of the Christian faith and Akan cultural values have been identified in specific areas like marriage, naming ceremony, funerals, use of symbols, festivals and protocols. Jesus the Lord and Saviour of the Christians has been noted and accepted as Chief. Ohene Yesu is celebrated in songs, prayers and sermons.

\footnotetext{
49 Interview with Kwabena Nketia May 19, 2004 Madina Accra.
} 
The study concludes with visitation on Rattray's call for attachment of pride and respect to Akan cultural values. Akan Christians must discontinue the tensions, unsympathetic attitudes, shame and inferiority complex towards their own cultural values. There is a need for an intentional exploration into the indigenous knowledge systems to discover the best in the cultural values that must be allowed to facilitate Christian expression and understanding with the firm conviction that the Akan indigenous heritage that was once handed over to Akan Christians are still in existence and must be allowed to serve Akan Christianity.

\section{ABOUT AUTHOR}

Kwabena Opuni-Frimpong (PhD), Lecturer in African Christianity, Department of Religious Studies, Kwame Nkrumah University of Science and Technology, Kumasi - Ghana.

\section{BIBLIOGRAPHY}

Bediako, Kwame. Theology and Identity The impact of culture upon Christian thought in the second century and modern Africa. Oxford: Regnum Books, 1992.

Gyekye, Kwame. African Cultural Values, Accra: Sankofa Publishing Company 1996.

Nana Addo Dankwa III, The Institution of Chieftaincy in Ghana - The Future. Accra: Konrad Adenauer Foundation, 2004

Odotei, Irene and George Hagan, The King Returns: Enstoolment of Asantehene Osei Tutu II. Accra: Institute of African Studies, 2002.

Rattray, R. S. Ashanti. London: Oxford University Press 1955. . Religion and Art in Ashanti. London: Oxford University Press, 1927. Ashanti Law and Constitution. London: Oxford University Press, 1929 . Ashanti Proverbs. London: Oxford University Press, 1916

Report of Presbyterian Church of Ghana Ministers Conference held at KNUST Kumasi on January 10-14, 2011.

Schreiter, Robert J. Constructing Local Theologies. New York: Orbis Books, 1985.

Smith, Noel. The Presbyterian Church of Ghana 1835-1960. Accra: Ghana University Press, 1966.

Walls, Andrew. The Cross-Cultural Process in Christian History. New York: Orbis Books, 2002.

Williamson, S.G. Akan Religion and the Christian Faith, Accra: Ghana University Press, 1965.

\section{APPENDIX}

Interview with Nana Addo Dankwa III November 22, 2004 Akropong Akuapem. Interview with Kwabena Nketia May 19, 2004 Madina Accra.

Interview with Okyeame Ampratwum June 1, 2004 Asante Mampong. Interview with Rev Dr Sam Prempeh September 1, 2004 Osu Accra. 